\title{
Revisão: Aspectos gerais das bacteriocinas
}

Review: General aspects of bacteriocins

\section{Autores | Authors}

\section{Mayara Baptistucci OGAKI}

Márcia Cristina FURLANETO

Universidade Estadual de Londrina (UEL)

Centro de Ciências Biológicas

Departamento de Microbiologia

Campus Universitário

Londrina/PR - Brasil

e-mail: mayaraogaki@hotmail.com furlaneto@uel.br

*Luciana Furlaneto MAIA

Universidade Tecnológica Federal do Paraná (UTFPR)

Departamento de Tecnologia em Alimentos Avenida dos Pioneiros, 3131

CEP: $86036-370$

Londrina/PR - Brasil

e-mail: Iucianamaia@utfpr.edu.br

*Autor Correspondente / Corresponding Author

Recebido: Maio 06, 2015

Aprovado: Jan. 07, 2016

\section{Resumo}

Bacteriocinas são peptídeos antimicrobianos sintetizados nos ribossomos, tendo sido descrita uma grande diversidade de bacteriocinas, as quais diferem entre si quanto a composição de aminoácidos, biossíntese, transporte e modo de ação. Nos alimentos, as bacteriocinas podem ser encontradas naturalmente como produtos da microbiota normal ou introduzida (cultura starter ou probióticos). Devido às suas aplicabilidades frente a organismos patogênicos contaminantes em alimentos, vários estudos têm sido publicados, tornando o uso destes peptídeos uma alternativa aos conservantes químicos tradicionais. Considerando-se as propriedades das bacteriocinas e sua potencial aplicação como bioconservadores de alimentos e alternativa aos antibióticos, o presente estudo busca acercar-se de uma visão geral das bacteriocinas quanto aos aspectos históricos, sistemas de classificação, biossíntese e transporte, modo de ação, abordando também algumas de suas aplicações na indústria de alimentos.

Palavras-chave: Bacteriocinas; Peptídeos antimicrobianos; Aplicações industriais; Bioconservantes.

\section{Summary}

Bacteriocins are antimicrobial peptides synthesized in the ribosomes. A wide variety of bacteriocins have been described, which differ in their amino acid composition, biosynthesis, transport and mode of action. Bacteriocins can be found naturally in foods as products of normal or added (starters or probiotics) microbiota in several preparations. Due to their applicability against pathogenic contaminants in food, various studies have been published making the use of these peptides an alternative to traditional chemical preservatives. Considering the properties of bacteriocins and their potential application as bio-preservatives in foods and alternatives to antibiotics, this study presents an overview of bacteriocins with respect to their historical aspects, classification systems, biosynthesis and transport and mode of action, also presenting some applications in food industries.

Key words: Bacteriocins; Antimicrobial peptides; Industrial applications; Bio-preservation. 


\section{Introdução}

As interações entre os micro-organismos em diferentes ambientes são complexas, sendo a competição intensamente presente; portanto, a produção de compostos antagônicos, como as bacteriocinas, está intimamente relacionada à competição em um mesmo nicho ecológico, representando uma característica vantajosa por parte do micro-organismo produtor (AND; HOOVER, 2003; CLEVELAND et al., 2001).

São bacteriocinas as nisinas, pediocinas, lacticinas, lactococinas, leuconocinas, plantaricinas, enterocinas, carnobacteriocinas, entre outras. Em geral, são catiônicas e exibem propriedades anfipáticas, sendo a membrana bacteriana, na maioria das vezes, o alvo de sua atividade. Tais substâncias podem ser produzidas tanto por bactérias Gram-positivas como por Gram-negativas, diferindo-se em tamanho, alvo microbiano, modo de ação, liberação e mecanismos de imunidade (CLEVELAND et al., 2001; GILLOR et al., 2008; SAVADOGO et al., 2006).

As primeiras bacteriocinas caracterizadas foram de bactérias Gram-negativas (por exemplo, colicinas de E. coli) e inicialmente atraíram a atenção dos pesquisadores devido à sua capacidade de interferir, por efeito bactericida ou bacteriostático, no crescimento de outras bactérias de espécies relacionadas. Tais efeitos inibitórios resultam da ação desses peptídeos antimicrobianos na permeabilização da membrana, na inibição da síntese de parede celular ou na inibição da atividade de DNA girase e RNA polimerase da célula- alvo.

Bacteriocinas de bactérias Gram-positivas, incluindo as que são produzidas por bactérias ácido-lácticas (BAL), têm atraído grande atenção por causa do seu status GRAS (Generally Recognized as Safe) e do seu uso potencial como aditivo seguro para a conservação de alimentos. Essas bacteriocinas são peptídeos pequenos, termoestáveis e de espectro antibacteriano restrito a amplo, podendo inibir o crescimento de bactérias patogênicas Gram-positivas, leveduras e algumas espécies de bactérias Gram-negativas. Diversas espécies de BAL já foram testadas quanto ao seu potencial de produção de bacteriocinas, tais como Enterococcus faecium, E. faecalis, E. mundtii, Lactobacillus sp., Lactococcus sp., Pediococcus sp., Carnobacterium piscicola, entre outras (CLEVELAND et al., 2001; DHEWA, 2012).

\section{Aspectos históricos}

Gratia (1925) relatou pela primeira vez a produção de colicina (princípio V) por uma amostra virulenta de Escherichia coli (GILLOR et al., 2008). Anos depois, o conhecimento das colicinas avançou muito com pesquisas realizadas por Fredericq (1946), que tentou adotar um termo que agrupasse todas essas substâncias antibacterianas produzidas pela família Enterobacteriaceae. Porém, as tentativas de categorizar as estafilococcinas de uma maneira semelhante às colicinas não foram bem sucedidas (CASCALES et al., 2007). Posteriormente, Jacob et al. (1953) introduziram o termo bacteriocinas, para designar proteínas bactericidas, as quais eram caracterizadas pela biossíntese letal, pelo espectro restrito de atividade e pela sua ligação específica a determinados receptores celulares (AND; HOOVER, 2003). As famílias de novas bacteriocinas passariam a ter o nome do gênero ou da espécie da bactéria produtora com o sufixo "cin" (CASCALES et al., 2007).

Atualmente, o termo "bacteriocinas" refere-se a peptídeos antimicrobianos, sintetizados nos ribossomos, que atuam contra bactérias Gram-positivas e Gram-negativas, sendo a bactéria produtora, portadora de mecanismos de imunidade específicos que a protegem de sua própria bacteriocina (AND; HOOVER, 2003; COTTER et al., 2013).

Com base em estudos bioquímicos e genéticos, várias bacteriocinas já foram caracterizadas, como, por exemplos: lactocinas (UPRETI; HINSDILL, 1975), lactococcinas (HOLO et al., 1991), plantaricinas (NISSEN-MEYER et al., 1993), pediocinas (CINTAS et al., 1995), enterocinas (AYMERICH et al., 1996), entre outras. Porém, apenas a nisina é aprovada pela Organização Mundial de Saúde desde 1969, sendo a única bacteriocina largamente comercializada e utilizada como conservante de alimentos em mais de 40 países, incluindo o Brasil (AND; HOOVER, 2003; CLEVELAND et al., 2001).

A nisina tem sido usada como conservante em alimentos há mais de 50 anos (CLEVELAND et al., 2001), desde que Rogers (1928) relatou a inibição de Lactobacillus bulgaricus por uma substância específica produzida por Lactococcus lactis. Mattick e Hirsch (1947) concentraram tal substância e a denominaram nisina. Anos depois, Gross e Morell (1971) caracterizaram-na estruturalmente como um peptídeo antimicrobiano que contém lantionina. Atualmente, o interesse por outras bacteriocinas além da nisina tem aumentado, devido à sua aplicação como conservantes alimentares (Tabela 1). Além da extensa aplicabilidade como probióticos e bioconservantes de alimentos, as bacteriocinas também são de grande interesse clínico e farmacêutico, pois atuam como alternativa aos antibióticos convencionais no tratamento de doenças associadas a patógenos microbianos, como, por exemplos, E. colienterotoxigênica e Campylobacter jejuni; também há relatos de atividade anticâncer de colicina A, produzida por cepas de E. coli, em células leucêmicas P388, e de nisina inibindo o crescimento de células tumorais HNSCC (YANG et al., 2014). 


\section{Classificação das bacteriocinas}

A classificação das bacteriocinas ainda é bastante controversa, sendo comum duas designações para uma mesma bacteriocina, dependendo do autor (Figura 1).

Bacteriocinas produzidas por BAL podem ser agrupadas em quatro grandes grupos, com base em sua estrutura, como, por exemplo, similaridades entre a sequência primária, propriedades físico-químicas, sequência-líder e número de peptídeos que constituem sua atividade; podem ser também agrupadas, principalmente, com base em seu modo de ação (AYMERICH et al., 1996). As bacteriocinas de BAL já foram agrupadas de diversas maneiras, porém ainda há falta de consenso quanto à sua classificação.
Klaenhammer (1993) definiu quatro classes de bacteriocinas produzidas por BAL. A Classe I refere-se aos lantibióticos, que constitui um grupo de peptídeos pequenos, sintetizados nos ribossomos, que sofrem extensa modificação pós-traducional. Estes contêm resíduos de lantionina e $\beta$-metil lantionina, bem como outros aminoácidos, como didehidroalanina e didehidrobutirina. A Classe II inclui os peptídeos pequenos (de 4 a 6 kDa), termoestáveis, sintetizados nos ribossomos, e que não sofrem extensa modificação pós-traducional, exceto a clivagem do peptídeo durante o transporte para fora da célula. A Classe II é dividida por Klaenhammer (1993) em três subgrupos: Ila, Ilb e Ilc. As bacteriocinas de Classe III são peptídeos termolábeis maiores que 30 kDa e as da Classe IV compreendem complexos de bacteriocinas que

Tabela 1. Bacteriocinas e suas aplicações como conservadores de alimentos.

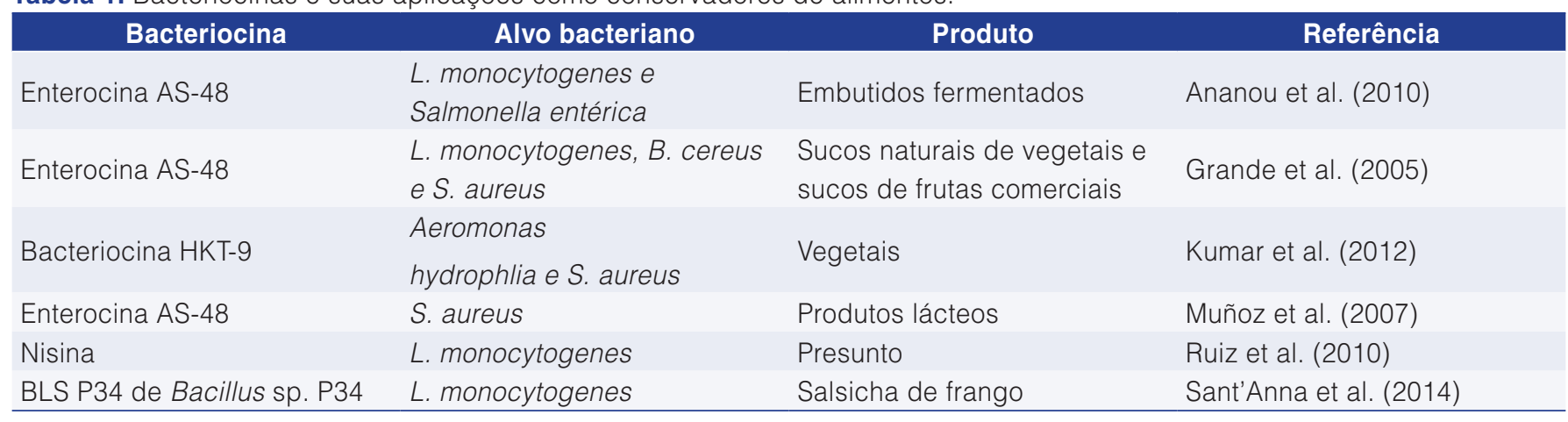

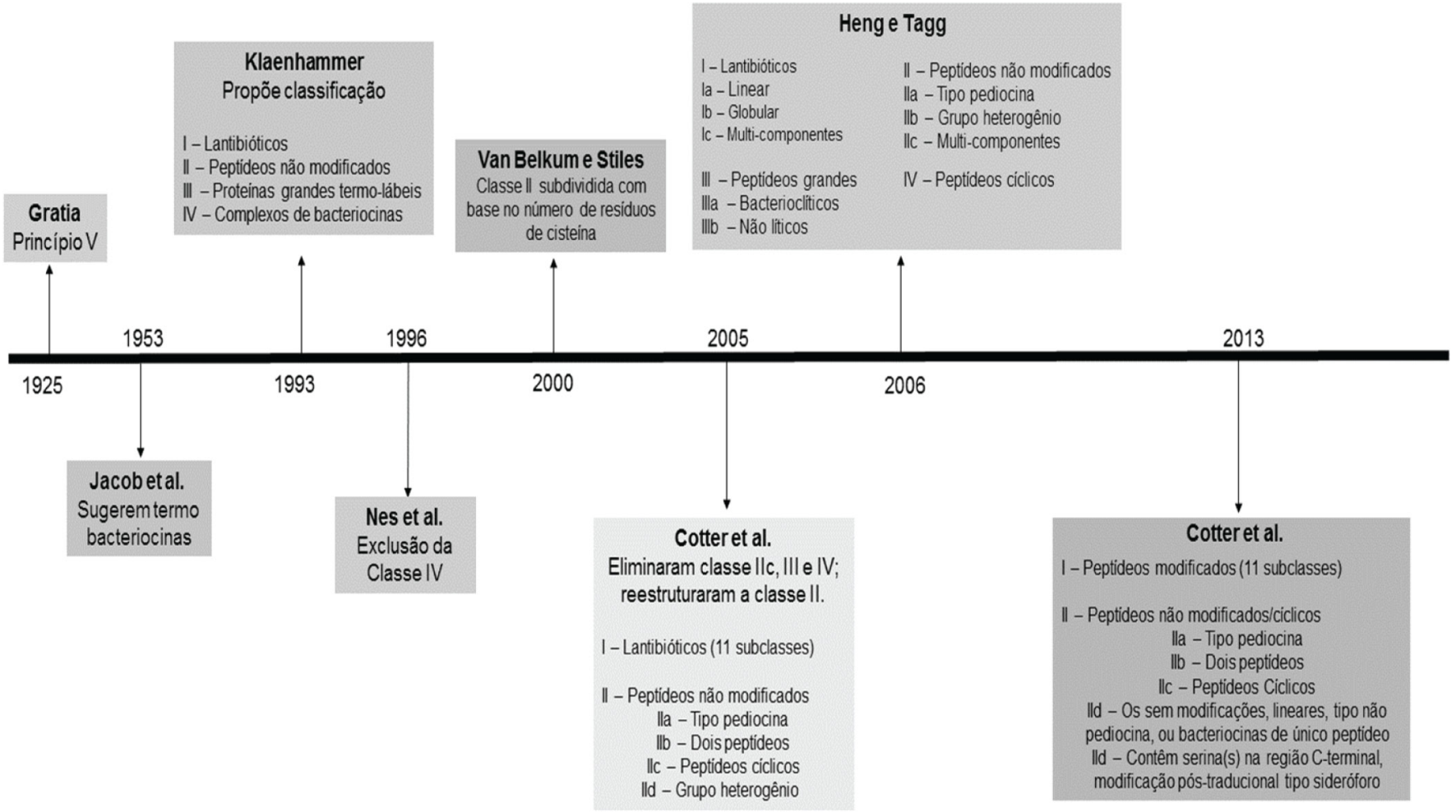

Figura 1. Classificações cronológicas das bacteriocinas. 
contêm lipídeos essenciais ou porções de carboidratos ligados a proteínas.

No sistema de classificação proposto por Nes et al. (2007), os autores excluíram as bacteriocinas de Classe IV, por não terem sido caracterizadas. Já na classificação proposta por Van Belkum e Stiles (2000), as bacteriocinas de Classe II foram subdivididas com base no número de resíduos de cisteína. Nesta classificação, as bacteriocinas secretadas pela via pré-peptídeo translocase (Sec) não seriam classificadas como um grupo separado, devido à diversidade de bacteriocinas secretadas por esta via.

Uma classificação simplificada em três grupos principais foi sugerida por Cotter et al. (2005), sendo a Classe I, os lantibióticos (bacteriocinas que contêm lantionina); a Classe II, os não lantibióticos (bacteriocinas que não contêm lantionina); a Classe III, as bacteriolisinas (peptídeos líticos), e a Classe IV (bacteriocinas com porções não proteicas) não foi inclusa na classificação. Já as bacteriocinas circulares, segundo tal classificação, pertencem à Classe II de peptídeos não modificados, de subclasse Ilc. Porém, tem-se sugerido uma nova classe IV ou V, que agregue essas bacteriocinas, já que estas se distinguem das demais produzidas por Gram-positivas, e por serem consideradas um grupo único devido à sua homogeneidade (GABRIELSEN et al., 2014).

Ponderando-se a necessidade de uma classificação universal, Heng e Tagg (2006) construíram um esquema de classificação que incluía elementos adotados por Klaenhammer (1993) e Cotter et al. (2005). Também propuseram a subdivisão da Classe I em la (lantibióticos lineares), Ib (globulares) e lc (multicomponentes).

Com base na classificação universal proposta por Heng e Tagg (2006), Nes et al. (2007) também propuseram duas classes para incluir bacteriocinas produzidas por Enterococcus e Streptococcus. Porém, não detalharam a Classe III, que inclui peptídeos termolábeis que degradam a parede de células-alvo, pois a inclusão desta terceira classe tem sido questionada. Segundo essa classificação, a Classe I inclui os lantibióticos e a Classe II é subdividida em Ila (peptídeos tipo pediocina), Ilb (bacteriocinas com dois peptídeos), Ilc (bacteriocinas sem peptídeos-líder) e Ild (peptídeos cíclicos). Autores como Kjos et al. (2011) já a abordaram para categorizar diversas bacteriocinas.

Considerando-se as inúmeras divergências com as classificações das bacteriocinas, uma nova classificação foi proposta recentemente por Cotter et al. (2013). Essa nova classificação separa as bacteriocinas produzidas por Gram-positivas das que são produzidas por Gram-negativas. As bacteriocinas de Gram-positivas são divididas em apenas duas Classes, I e II, excluindo as Classes III e IV propostas até então. A Classe III seria inclusa na Classe II em uma nova subdivisão Ilc e a Classe IV não entraria na classificação, pois a designação de bacteriocinas corresponderia apenas aos peptídeos pequenos ribossomalmente sintetizados, não incluindo outras proteínas antimicrobianas grandes.

Segundo a nova classificação, a Classe I corresponde às bacteriocinas que sofrem extensas modificações pós-traducionais e a Classe II engloba as bacteriocinas que não sofrem tais modificações e também as que sofrem modificações modestas, como a formação de pontes dissulfeto, a circularização ou a adição de $\mathrm{N}$-formilmetionina. Já as bacteriocinas de Gram-negativas pertenceriam a dois grupos distintos, um de peptídeos pequenos, como as microcinas, e um segundo de peptídeos grandes, as colicinas.

As Classes I e II de bacteriocinas de Gram-positivas também teriam subdivisões com base nas modificações que sofrem após a tradução. Em uma publicação recente, autores como Yang et al. (2014) já adotaram essa nova classificação.

\section{Biossíntese e transporte}

A produção de bacteriocinas ocorre em todas as fases de crescimento da bactéria produtora e cessa no final da fase exponencial. Sua indução muitas vezes ocorre em condições de estresse, como o aumento populacional e a escassez de nutrientes, podendo ser afetada pelo tipo de fonte de carbono, nitrogênio e fosfato presentes no meio, ou até mesmo por cátions surfactantes e outros inibidores (RILEY, 2011; SAVADOGO et al., 2006).

A síntese das bacteriocinas envolve quatro genes: (1) o gene responsável pela produção do pré-peptídeo; (2) o gene de imunidade específica que confere a produção de uma proteína de imunidade à célula produtora; (3) o gene que codifica proteínas do transportador $A B C$, responsável por exteriorizar a bacteriocina, e (4) o gene que codifica uma proteína acessória essencial para a exteriorização da bacteriocina, cuja função não está totalmente esclarecida. Esses genes estão organizados em um ou dois operons (NES et al., 2007). Por exemplo, as enterocinas A e B possuem genes organizados em dois operons, referentes aos loci entA e entB, baseado no estudo de Nes et al. (2007). Em espécies como $S$. thermophilus e E. faecium, a produção de bacteriocina é regulada por indutores específicos, os peptídeos feromônios. A regulação da expressão de bacteriocinas ocorre quando o peptídeo feromônio, sintetizado nos ribossomos como pré-peptídeos, sofrem clivagem e são transportados extracelularmente. Quando os feromônios atingem um limiar de concentração específico, se ligam aos receptores da proteína quinase histidina (HPK) presentes na membrana celular, fosforilando o resíduo de histidina e o regulador de resposta que se liga à região promotora do gene de bacteriocina, ativando a expressão (BALCIUNAS et al., 2013; NES et al., 2007).

A maioria das bacteriocinas é sintetizada inicialmente na forma de um pré-peptídeo biologicamente 
inativo, que consiste em um peptídeo-líder N-terminal e um pró-peptídeo C-terminal. Em geral, a ligação do peptídeo-líder mantém as bacteriocinas inativas antes de serem exportadas da célula produtora (NISHIE et al., 2012).

Nos lantibióticos (Classe I), o pró-peptídeo possui resíduos de serina, treonina e cisteína, que sofrem modificação pós-traducional, formando Lan/MeLan (AND; HOOVER, 2003). Os pré-peptídeos são constituídos por uma sequência-líder de 14 a 30 aminoácidos na região N-terminal, a qual é removida durante a maturação da proteína. As etapas que envolvem a maturação são: 1) Síntese do pré-peptídeo; 2) clivagem subsequente do mesmo num local de processamento específico, em que há a remoção da sequência N-terminal, e 3) concomitantemente à clivagem, ocorre sua exportação para o exterior da célula (ENNAHAR et al., 2000). Com base na biossíntese, os lantibióticos podem ser subdivididos em dois grupos: no grupo I, o pré-peptídeo sofre desidratação pela enzima LanB e, posteriormente, formação de uma ligação tio-éter pela enzima LanC. Em seguida, o pré-peptídeo sofre modificações pela protease serina LanP e é translocado em sua forma madura através da membrana, pelas proteínas LanT do transportador tipo ABC. Já no grupo II, o pré-peptídeo é extensivamente modificado por uma única enzima LanM e o processamento é concomitante à translocação pela enzima LanT(P) (AND; HOOVER, 2003). Após a liberação da bacteriocina, uma proteína histidina quinase (HPK) detecta a presença de bacteriocinas e se autofosforila. O grupo fosfato é transferido a um regulador de resposta (RR) que ativa a transcrição de genes reguladores; assim, proteínas de imunidade (Lanl) e as dedicadas ao transportador ABC (LanFEG) são produzidas (AND; HOOVER, 2003).

As bacteriocinas Classe II são sintetizadas como pré-peptídeos tipo dupla glicina. Na região N-terminal dos pré-peptídeos, há dois resíduos de glicina conservados, que têm por funções: impedir a bacteriocina de ser biologicamente ativa intracelularmente e fornecer o sinal de reconhecimento para o transportador $A B C$. Inicialmente, ocorre a síntese do pré-peptídeo e também de um fator de indução (IF); em seguida, os pré-peptídeos tipo dupla-glicina são exportados através da membrana citoplasmática por um cassete transportador ligado a ATP (ABC). O transportador ABC é uma protease, cujo domínio proteolítico reside na região $\mathrm{N}$-terminal da proteína; portanto, tem por função a remoção da sequência-líder e a translocação do peptídeo maduro através da membrana citoplasmática. O transporte por ABC está envolvido na translocação de diferentes substratos, como íons, carboidratos, aminoácidos, vitaminas, lipídeos e antibióticos, além de moléculas maiores, como oligossacarídeos, oligopeptídeos e proteínas de elevado peso molecular (BIEMANS-OLDEHINKEL et al., 2006).

Após a liberação da bacteriocina, a HPK detecta a presença do fator de indução e se autofosforila; o grupo fosfato $(P)$ é transferido para o regulador $R R$, que ativa a transcrição de genes regulados e a produção da proteína de imunidade, ocorrendo de maneira similar à Classe I (AND; HOOVER, 2003).

A presença ou ausência da extensão $\mathrm{N}$-terminal no pré-peptídeo determina o mecanismo de secreção das bacteriocinas da Classe II. Até agora, as enterocinas L50A, L50B, Q e a bacteriocina LsbB são os únicos exemplos de bacteriocinas Classe II que são sintetizadas sem extensão N-terminal, sendo seus mecanismos de secreção desconhecidos (HERRANZ; DRIESSEN, 2005). Outras exceções, como as bacteriocinas circulares, pertencentes à Classe $\|_{\mathrm{l}}$, distinguem-se das demais por suas porções N e C terminal estarem covalentemente ligadas (estruturalmente circularizadas); porém, também são sintetizadas na forma de pré-peptídeos lineares, que são clivados para sua ativação (GABRIELSEN et al., 2014). A maioria das bacteriocinas de Classe II contém o sinal tipo dupla-glicina; porém, outras apresentam um pré-peptídeo do tipo Sec-dependente, transportado pela via Sec-translocase, como, por exemplos, as bacteriocinas divergicina A (Carnobacterium divergens), acidocina B (Lactobacillus acidophilus), bacteriocina 31 (E. faecalis) e enterocina P (E. faecium) (CINTAS et al., 1997; HERRANZ; DRIESSEN, 2005). Os pré-peptídeos do tipo Sec-dependente da bacteriocina 31, por exemplo, possuem uma sequência com três resíduos de aminoácidos básicos (Arg/Lys-Lys-Lys) próximos à região $\mathrm{N}$-terminal e ao sítio de clivagem Val-X-Ala (nas posições 23-21), o qual contém um resíduo ácido (Asp ou Glu) na posição 22 (CINTAS et al., 1997).

O movimento dos pré-peptídeos do tipo Sec através da membrana plasmática é mediado por um complexo de proteínas multiméricas citosólicas e presentes na membrana, chamado de translocase. A translocação de proteínas para o exterior das células é acionada por meio de hidrólise de ATP e por força próton motora. O esquema de transporte de bacteriocinas pela via Sec translocase está representado na Figura 2 (FELTCHER; BRAUNSTEIN, 2012).

\section{Mecanismos de ação}

A maioria das bacteriocinas interage com lipídeos aniônicos presentes na membrana plasmática das bactérias-alvo, sendo ativas principalmente contra bactérias Gram-positivas, já que estas são caracterizadas por um elevado teor de lipídeos aniônicos na membrana (ZACHAROF; LOVITT, 2012; GUILHELMELLI et al., 2013). A maioria das bacteriocinas age permeabilizando a membrana por meio da formação de poros, o que promove 


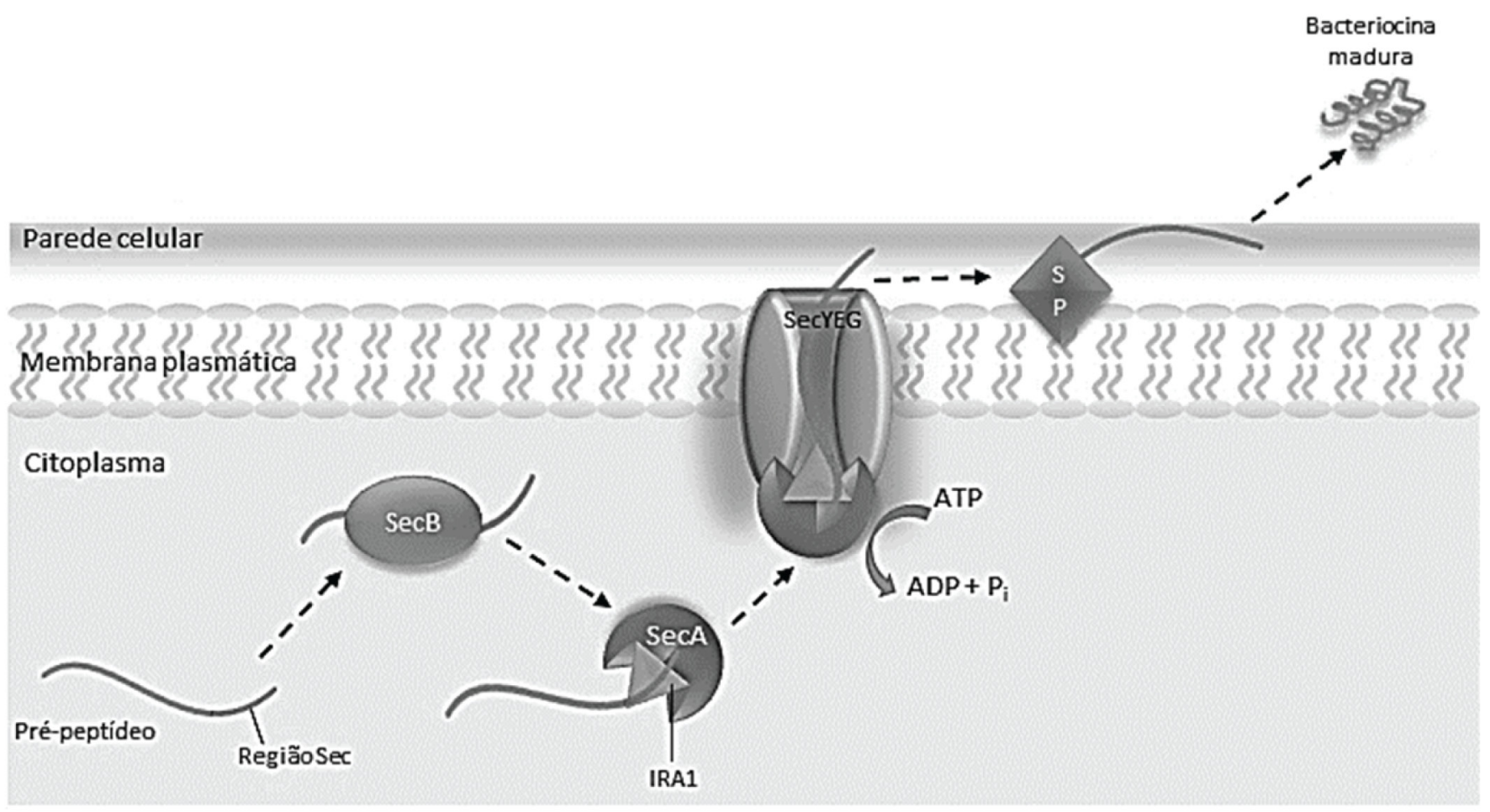

Figura 2. Pré-peptídeos são sintetizados nos ribossomos com uma sequência Sec N-terminal; depois, são capturados por uma chaperona SecB que os mantém desenrolados e os direcionam à proteína SecA. A proteína citoplasmática SecA possui dois domínios: um domínio motor que aciona a hidrólise de ATP e outro específico, que interage com o pré-peptídeo, o qual se liga a uma fenda entre os dois domínios. SecA auxilia na translocação dos pré-peptídeos gradualmente pelo canal SecYEG. O pré-peptídeo se insere para manter o canal aberto e a proteína SecA também é inserida pela dupla hélice IRA1 (regulador intramolecular de hidrólise de ATP1). Após a translocação, a sequência Sec é removida do pré-peptídeo por peptidases periplásmicas de sinal (SP) e, consequentemente, há a formação da bacteriocina madura (FELTCHER; BRAUNSTEIN, 2012; LYCKLAMA; DRIESSEN, 2012).

a dissipação da força próton motora (PMF) e a inibição do transporte de aminoácidos. A PMF está envolvida em diversos processos na membrana citoplasmática, tais como o acúmulo de íons e metabólitos, e a síntese de ATP. Outras bacteriocinas podem inibir também bactérias Gram-negativas; porém, estas necessitam transpor a membrana externa da parede celular e alcançar a membrana plasmática da célula-alvo para atuarem. Em contato com a membrana plasmática, são capazes de interferir na síntese de DNA, RNA e proteínas, como algumas microcinas (Mcc), por exemplos: a MccB17 inibe a DNA-girase, a MccJ25 inibe a RNA polimerase e a MccC7-C51 inibe a aspartil-RNAt sintase. Há também exceções, como a MccE4492, que atua por meio da formação de poros (COTTER et al., 2013).

Os lantibióticos possuem um amplo espectro de ação e geralmente formam poros instáveis; porém, algumas moléculas de ancoragem presentes na membrana-alvo podem funcionar como receptores, aumentando a condutividade e a estabilidade dos poros (MOLL et al., 1999). Alguns membros da Classe I, como a nisina, têm modo de ação duplo (Figura 3). Os lipídeos II, presentes na membrana-alvo, são os principais transportadores de subunidades de peptidoglicano do citoplasma para a parede celular e a nisina se liga ao lipídeo II, impedindo a síntese correta da parede celular. Além disso, o lipídeo II pode atuar como uma molécula de ancoragem a que a nisina se liga para se inserir na membrana, formando poros. Além da nisina, a lacticina 3147, lantibiótico com dois peptídeos, apresenta sua atividade distribuída em dois peptídeos, enquanto a mersacidina se liga apenas aos lipídeos II, sem formar poros (COTTER et al., 2005).

As bacteriocinas de Classe II são termoestáveis com espectro restrito de atividade, sendo os receptores na membrana da célula-alvo que determinam sua especificidade de ligação. Em geral, possuem uma estrutura helicoidal anfifílica, o que Ihes permite inserir na membrana da célula-alvo, conduzindo à despolarização por dissipação da PMF; consequentemente, há o desequilíbrio do conteúdo intracelular (COTTER et al., 2005; MOLL et al. 1999).

Bacteriocinas Classe III ou bacteriolisinas, como a lisostafina, podem funcionar diretamente sobre a parede celular de bactérias Gram-positivas-alvo, causando sua lise (COTTER et al., 2005). 


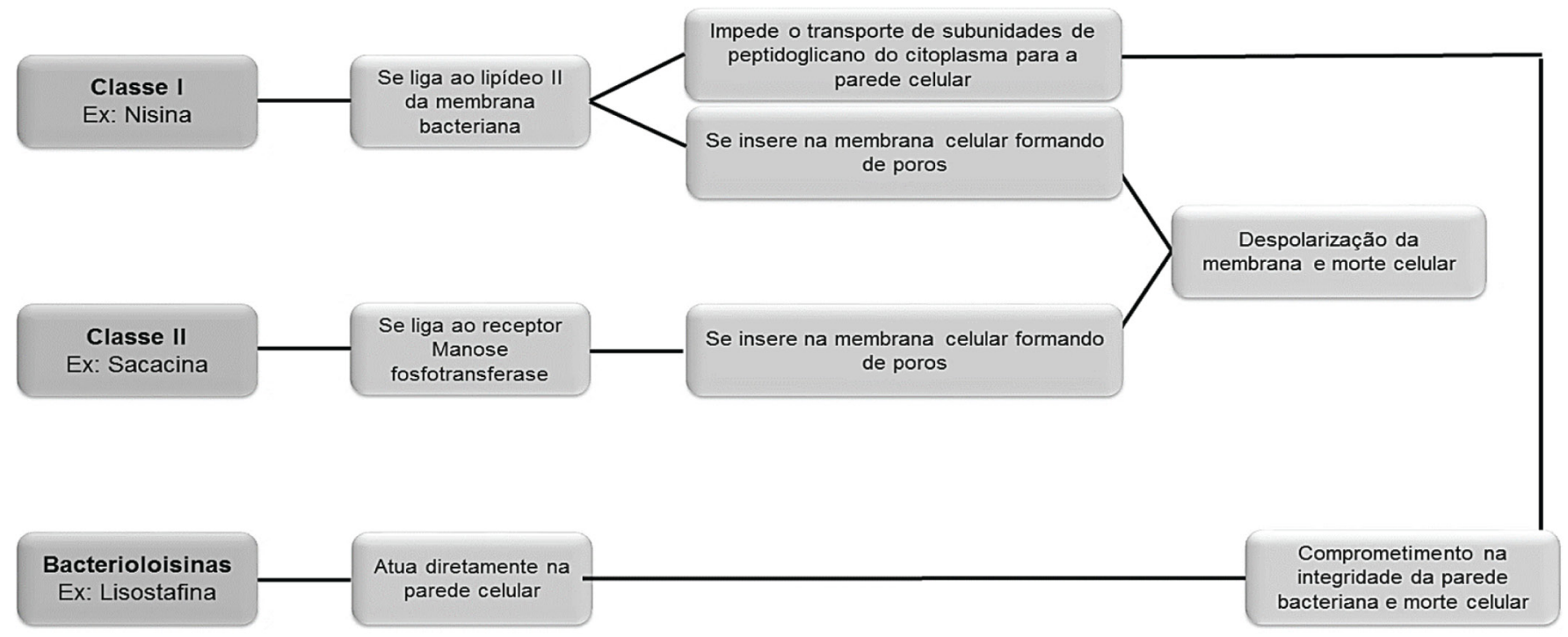

Figura 3. Modo de ação de bacteriocinas sintetizadas por BAL.

Existem dois modelos que simulam o mecanismo de ação de peptídeos líticos com características anfipáticas sobre a membrana plasmática: os modelos Wedge-like e Barrel stave, representados na Figura 4, baseada no estudo de Moll et al. (1999) e Rosa e Franco (2002). Estes diferem quanto à forma de inserção da bacteriocina na membrana da célula-alvo.

A nisina, uma bacteriocina Classe I, apresenta pelo menos três tipos de atividade antimicrobiana além da formação de poros na membrana citoplasmática: é capaz de inibir a germinação de esporos bacterianos, a biossíntese da parede celular e a atividade de enzimas autolíticas (MOLL et al., 1999).

Um exemplo do mecanismo de ação das bacteriocinas Classe ll é o da lactococcina: os monômeros de lactococcina se ligam a um receptor de membrana (manose-fosfotransferase - ManPTS), se inserem e dão origem aos poros (COTTER et al., 2013). Porém, estudos recentes identificaram que bacteriocinas cíclicas, subclasse Ilc (garvicina ML) e bacteriocinas subclasse Ild (lactococcina LsbB) possuem receptores de membrana diferentes de Man-PTS (COTTER, 2014).

Bacteriocinas subclasse IIc, como a enterocina AS-48, a garvicina e a circularina, possuem uma estrutura globular compacta composta por porções helicoidais repetidas ao redor de um núcleo hidrofóbico, característica que as tornam altamente estáveis e resistentes a alta temperatura, maiores variações de $\mathrm{pH}$ e ação proteolítica (GABRIELSEN et al., 2012). Recentemente, estudos relataram que a atividade antimicrobiana de bacteriocinas cíclicas, como a garvicina ML, está intimamente relacionada ao receptor de membrana maltose $A B C$ transportador, que pode atuar como permease ou molécula de ancoragem para a ligação e a atividade do peptídeo (COTTER, 2014; GABRIELSEN et al., 2012). Já bacteriocinas, como a lactococcina LsbB, pertencente à subclasse $\mathrm{Ild}$, possuem, como receptor, metalopeptidades zinco-dependentes presentes na membrana plasmática das células-alvo (UZELAC et al., 2013). A bactéria produtora de bacteriocina possui um mecanismo de imunidade que a protege da ação de suas próprias bacteriocinas, a fim de evitar a lise da própria célula e de células análogas (BENZ; MEINHART, 2014). A proteção é conferida por um peptídeo de imunidade expresso concomitantemente às bacteriocinas (ABEE et al., 1995; BENZ; MEINHART, 2014). A proteína de imunidade pode estar fracamente associada ou não associada às proteínas receptoras de membrana (manose fosfotransferase - Man-PTS). Quando a bacteriocina é produzida, a proteína de imunidade se liga ao receptor evitando que a bacteriocina se ligue a este e forme poros na membrana citoplasmática, o que provocaria a lise celular (NES et al., 2007).

Devido aos seus efeitos antimicrobianos, frequentemente as bacteriocinas são confundidas com antibióticos, o que, muitas vezes, por prejulgamento, pode inviabilizar seu uso em alimentos e na medicina. Porém, existem algumas características que as distinguem dos antibióticos (ANANOU et al., 2007; COTTER et al., 2013; GILLOR et al., 2008): i) são sintetizadas nos ribossomos; ii) possuem um espectro bactericida restrito; iii) atuam na formação de poros na membrana celular e/ou interferem na biossíntese de parede, proteínas, DNA e RNA; iv) possuem toxicidade desconhecida em células eucarióticas; v) as células produtoras possuem imunidade às bacteriocinas que produzem; vi) são, em geral, termorresistentes; vii) são inativas na presença de enzimas proteolíticas do trato gastrointestinal. 
Barrel stave

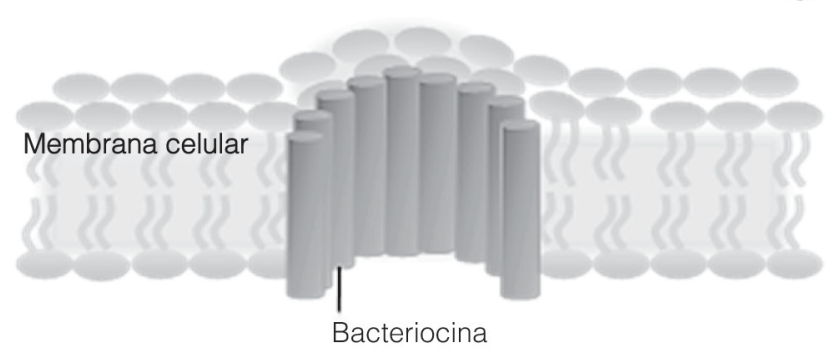

Wedge-like

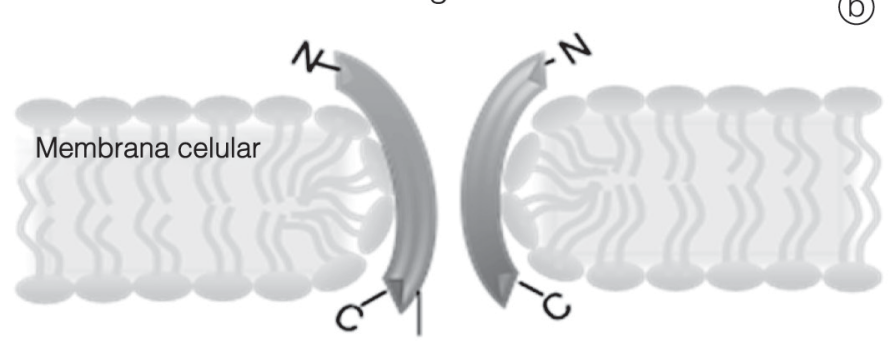

Bacteriocina

Figura 4. (a) Modelo Barrel stave; vários monômeros de bacteriocinas de classe Il atuam em conjunto, agregando-se lateralmente, para formar poros na membrana. A presença de um resíduo de aminoácido no meio da sequência do peptídeo facilita sua inserção na membrana, num estágio inicial de ligação. A molécula se liga ao receptor de ancoragem, a porção hidrofílica dos peptídeos em alfa-hélice fica voltada para a parede celular e a porção hidrofóbica desses peptídeos se liga às cadeias de ácidos graxos dos lipídios da membrana (MOLL et al., 1999; ROSA; FRANCO, 2002). (b) Modelo Wedge-like; bacteriocinas de classe I se ligam à superfície da membrana citoplasmática provocando sua desestabilização, com consequente formação de poros. PMF promove a inserção da porção C-terminal do peptídeo na bicamada lipídica; no entanto, o peptídeo não entra em contato com a parte hidrofóbica da membrana. Vários peptídeos inseridos podem dar origem a um local de perturbação, causando a formação de poros temporários lipídeo-proteína. Tais estruturas são intrinsecamente instáveis, devido às forças hidrofóbicas que irão conduzir os rearranjos dos lipídios na sua organização original em bicamada (MOLL et al., 1999).

\section{Conclusão}

Devido às características singulares das bacteriocinas, como, por exemplo, seu espectro antimicrobiano, estas têm se tornado atrativas à indústria alimentícia, como bioconservantes de alimentos, e também à indústria farmacêutica, como uma alternativa aos antibióticos de uso médico (devido à ação antimicrobiana em sítios-alvo, o que as distinguem dos antibióticos comumente usados) e também como compostos anticâncer. Consequentemente, tais aplicações acarretam grandes investimentos na área de pesquisa em busca de isolados que sejam potencialmente produtores e também por novas bacteriocinas, que tenham aplicação biotecnológica em diversas áreas. Portanto, novas pesquisas envolvendo esses peptídeos são de grande relevância.

\section{Referências}

ABEE, T.; KROCKEL, L.; HILL, C. Bacteriocins: modes of action and potentials in food preservation and control of food poisoning. International Journal of Food Microbiology, Oxford, v. 28, n. 2, p. 169-185, 1995. http://dx.doi.org/10.1016/01681605(95)00055-0. PMid:8750665.

ANANOU, S.; BAÑOS, A.; MAQUEDA, M.; MARTÍNEZ-BUENO, M.; GÁLVEZ, A.; VALDIVIA, E. Effect of combined physicochemical treatments based on enterocin AS-48 on the control of Listeria monocytogenes and Staphylococcus aureus in a model cooked ham. Food Control, Oxford, v. 21, n. 4, p. 478-486, 2010. http://dx.doi.org/10.1016/j.foodcont.2009.07.010.

ANANOU, S.; MAQUEDA, M.; MATÍNEZ-BUENO, M.; VALDIVIA, E. Biopreservation, ecological approach to improve the safety and shelf-life of foods. Communicating Current Research and Educational Topics and Trends in Applied Microbiology, Badajoz, v. 1, p. 475-486, 2007.

AND, H. C.; HOOVER, D. G. Bacteriocins and their food applications. Comprehensive Reviews in Food Science and Food Safety, Malden, v. 2, n. 3, p. 82-100, 2003. http://dx.doi. org/10.1111/j.1541-4337.2003.tb00016.x

AYMERICH, T.; HOLO, H.; HÅVARSTEIN, L. S.; HUGAS, M.; GARRIGA, M.; NES, I. F. Biochemical and genetic characterization of enterocin a from Enterococcus faecium, a new antilisterial bacteriocin in the pediocin family of bacteriocins. Applied and Environmental Microbiology, Washington, v. 62, n. 5, p. 1676-1682, 1996. PMid:8633865.

BALCIUNAS, E. M.; CASTILLO MARTINEZ, F. A.; TODOROV, S. D.; FRANCO, B. D. G. M.; CONVERTI, A.; OLIVEIRA, R. P. S.; MARTINEZ, F. A. C.; TODOROV, S. D.; FRANCO, B. D. G. M.; COVERTI, A.; OLIVEIRA, R. P. S. Novel biotechnological applications of bacteriocins: a review. Food Control, Guildford, v. 32, n. 1, p. 134-142, 2013. http://dx.doi.org/10.1016/j. foodcont.2012.11.025.

BENZ, J.; MEINHART, A. Antibacterial effector/immunity systems: it's just the tip of the iceberg. Current Opinion in Microbiology, Oxford, v. 17, p. 1-10, 2014. http://dx.doi.org/10.1016/j. mib.2013.11.002. PMid:24581686.

BIEMANS-OLDEHINKEL, E.; DOEVEN, M. K.; POOLMAN, B. $A B C$ transporter architecture and regulatory roles of accessory domains. FEBS letters, Heidelberg, v. 580, p. 1023-1035, 2006. CASCALES, E.; BUCHANAN, S. K.; DUCHE, D.; KLEANTHOUS, C.; LLOUBES, R.; POSTLE, K.; RILEY, M.; SLATIN, S.; CAVARD, D. Colicin biology. Microbiology and Molecular Biology 
Reviews, Washington, v. 71, n. 1, p. 158-229, 2007. http://dx.doi. org/10.1128/MMBR.00036-06. PMid:17347522.

CINTAS, L. M.; CASAUS, P.; HÅVARSTEIN, L. S.; HERNANDEZ, P. E.; NES, I. F. Biochemical and genetic characterization of enterocin P, a novel sec-dependent bacteriocin from Enterococcus faecium $\mathrm{P} 13$ with a broad antimicrobial spectrum. Applied and Environmental Microbiology, Washington, v. 63, n. 11, p. 4321-4330, 1997. PMid:9361419.

CINTAS, L. M.; RODRIGUEZ, J. M.; FERNANDEZ, M. F.; SLETTEN, K.; NES, I. F.; HERNANDEZ, P. E.; HOLO, H. Isolation and characterization of pediocin L50, a new bacteriocin from Pediococcus acidilactici with a broad inhibitory spectrum. Applied and Environmental Microbiology, Washington, v. 61, n. 7, p. 2643-2648, 1995. PMid:7618877.

CLEVELAND, J.; MONTVILLE, T.; NES, I. F.; CHIKINDAS, M. L. Bacteriocins: safe, natural antimicrobials for food preservation. International Journal of Food Microbiology, Oxford, v. 71, n. 1, p. 1-20, 2001. http://dx.doi.org/10.1016/S0168-1605(01)00560-8. PMid:11764886

COTTER, P. D. An 'Upp'-turn in bacteriocin receptor identification. Molecular Microbiology, Salem, v. 92, n. 6, p. 1159-1163, 2014. http://dx.doi.org/10.1111/mmi.12645. PMid:24811684.

COTTER, P. D.; HILL, C.; ROSS, R. P. Bacteriocins: developing innate immunity for food. Nature Reviews Microbiology, London, n. 3, p. 777-788, 2005.

COTTER, P. D.; ROSS, R. P.; HILL, C. Bacteriocins: a viable alternative to antibiotics? Nature Reviews Microbiology, London, n. 11, p. 95-105, 2013.

DHEWA, T. Screening, production purification and potential use of bacteriocins from lactic acid bacteria of meat and dairy food origin. In: INTERNATIONAL CONFERENCE ON NUTRITION AND FOOD SCIENCES, 2012, Singapore. Proceedings... Singapore: IACSIT Press, 2012. v. 39, p. 35-41.

ENNAHAR, S.; SASHIHARA, T.; SONOMOTO, K.; ISHIZAKI, A. Class Ila bacteriocins: biosynthesis, structure and activity. FEMS Microbiology Reviews, Oxford, v. 24, n. 1, p. 85-106, 2000. http://dx.doi.org/10.1111/j.1574-6976.2000.tb00534.x. PMid:10640600.

FELTCHER, M. E.; BRAUNSTEIN, M. Emerging themes in SecA2-mediated protein export. Nature Reviews Microbiology, London, v. 10, n. 11, p. 779-789, 2012. http://dx.doi.org/10.1038/ nrmicro2874. PMid:23000954.

GABRIELSEN, C.; BREDE, D. A.; HERNÁNDEZ, P. E.; NES, I. F.; DIEP, D. B. The maltose ABC transporter in Lactococcus lactis facilitates high-level sensitivity to the circular bacteriocin garvicin ML. Antimicrobial Agents and Chemotherapy, Bethesda, v. 56, n. 6, p. 2908-2915, 2012. http://dx.doi.org/10.1128/AAC.0031412. PMid:22411612.

GABRIELSEN, C.; BREDE, D. A.; NES, I. F.; DIEP, D. B. Circular bacteriocins: biosynthesis and mode of action. Applied and
Environmental Microbiology, Washington, v. 82, n. 2, p. 1-24, 2014.

GILLOR, O.; ETZION, A.; RILEY, M. A. The dual role of bacteriocins as anti- and probiotics. Applied Microbiology and Biotechnology, Heidelberg, v. 81, n. 4, p. 591-606, 2008. http://dx.doi.org/10.1007/s00253-008-1726-5. PMid:18853155.

GRANDE, M. J.; LUCAS, R.; VALDIVIA, E.; ABRIOUEL, H.; MAQUEDA, M.; OMAR, N. B.; MARTÍNEZ-CAÑAMERO, M.; GÁLVEZI, A. Stability of enterocin AS-48 in fruit and vegetable juices. Journal of Food Protection, Des Moines, v. 10, n. 10, p. 2085-2094, 2005. PMid:16245711.

GROSS, E.; MORELL, J. L. The structure of nisin. Journal of the American Chemical Society, Washington, v. 93, n. 18, p. 4634-4635, 1971. http://dx.doi.org/10.1021/ja00747a073. PMid:5131162.

GUILHELMELLI, F.; VILELA, N.; ALBUQUERQUE, P.; DERENGOWSKI, L. S.; SILVA-PEREIRA, I.; KYAW, C. M. Antibiotic development challenges: the various mechanisms of action of antimicrobial peptides and of bacterial resistance. Frontiers in Microbiology, Lausanne, v. 4, p. 1-12, 2013. http://dx.doi. org/10.3389/fmicb.2013.00353. PMid:24367355.

HENG, N. C. K.; TAGG, J. R. What's in a name? Class distinction for bacteriocins. Nature Reviews Microbiology, London, v. 4, 2006.

HERRANZ, C.; DRIESSEN, A. J. M. Sec-Mediated secretion of bacteriocin enterocin $\mathrm{P}$ by Lactococcus lactis. Applied and Environmental Microbiology, Washington, v. 71, n. 4, p. 1959-1963, 2005. http://dx.doi.org/10.1128/AEM.71.4.19591963.2005. PMid:15812026.

HOLO, H.; NILSSEN, O.; NES, I. F. Lactococcin A, a new bacteriocin from Lactococcus lactis subsp. cremoris: Isolation and characterization of the protein and its gene. Journal of Bacteriology, Washington, v. 173, n. 12, p. 3879-3887, 1991. PMid: 1904860.

KJOS, M.; BORRERO, B.; OPSATA, M.; BIRRI, D. J.; HOLO, H.; CINTAS, L. M.; SNIPEN, L.; HERNÁNDEZ, P. E.; NES, I. F.; DIEP, D. B. Target recognition, resistance, immunity and genome mining of class II bacteriocins from Gram-positive bactéria. Microbiology, London, v. 157, n. Pt 12, p. 3256-3267, 2011. http://dx.doi.org/10.1099/mic.0.052571-0. PMid:21980118.

KLAENHAMMER, T. R. Genetics of bacteriocins produced by lactic acid bacteria. FEMS Microbiology Reviews, Oxford, v. 12, n. 1-3, p. 39-85, 1993. http://dx.doi.org/10.1111/j.1574-6976.1993. tb00012.x. PMid:8398217.

KUMAR, M.; JAIN, A. K.; GHOSH, M.; GANGULI, A. Potential application of an anti-aeromonas bacteriocin of Lactococcus lactis ssp. lactis in the preservation of vegetable salad. Journal of Food Safety, Connecticut, v. 32, n. 3, p. 369-378, 2012. http:// dx.doi.org/10.1111/j.1745-4565.2012.00389.x. 
LYCKLAMA, J. A.; DRIESSEN, A. J. M. The bacterial Sec-translocase: Structure and mechanism. Philosophical Transactions of the Royal Society B, London, v. 367, p. 10161028, 2012.

MOLL, G. N.; KONINGS, W. N.; DRIESSEN, A. J. M. Bacteriocins: mechanism of membrane insertion and pore formation. Antonie Van Leeuwenhoek, Wageningen, v. 76, n. 1/4, p. 185-198, 1999. http://dx.doi.org/10.1023/A:1002002718501.

MUÑOZ, A.; ANANOU, S.; GÁLVEZ, A.; MARTíNEZ-BUENO, M.; RODRÍGUEZ, A.; MAQUEDA, M.; VALDIVIA, E. Inhibition of Staphylococcus aureus in dairy products by enterocin AS-48 produced in situ and ex situ: Bactericidal synergism with heat. International Dairy Journal, Oxford, v. 17, n. 7, p. 760-769, 2007. http://dx.doi.org/10.1016/j.idairyj.2006.09.006.

NES, I. F.; DIEP, D. B.; HOLO, H. Bacteriocin diversity in Streptococcus and Enterococcus. Journal of Bacteriology, Washington, v. 189, n. 4, p. 1189-1198, 2007. http://dx.doi. org/10.1128/JB.01254-06. PMid:17098898.

NISHIE, M.; NAGAO, J.-I.; SONOMOTO, K. Antibacterial peptides "bacteriocins": an overview of their diverse characteristics and applications. Biocontrol Science, Osaka, v. 17, n. 1, p. 1-6, 2012. http://dx.doi.org/10.4265/bio.17.1. PMid:22451427.

NISSEN-MEYER, J.; LARSEN, A. G.; SLETTEN, K.; DAESCHEL, M.; NES, I. F. Purification and characterization of plantaricin A, a Lactobacillus plantarum bacteriocin whose activity depends on the action of two peptides. Journal of General Microbiology, London, v. 139, n. 9, p. 1973-1978, 1993. http://dx.doi. org/10.1099/00221287-139-9-1973. PMid:8245827.

RILEY, M. A. Bacteriocin mediated competitive interactions of bacterial populations and communities. In: DRIDER, D.; REBUFFAT, S. (Eds.). Prokaryotic antimicrobial peptides. London: Springer, 2011. p. 13-26.

ROGERS, L. A. The inhibiting effect of Streptococcus lactis on Lactobacillus bulgaricus. Journal of Bacteriology, v. 16, n. 5, p. 321-325, 1928. PMid:16559344.

ROSA, M. C.; FRANCO, B. D. Bacteriocinas de bactérias lácticas. Conscientiae Saúde, São Paulo, v. 1, p. 09-15, 2002.

RUIZ, A.; WILLIAMS, S. K.; DJERI, N.; HINTON, A. J. Jr; RODRICK, $\mathrm{G}$. E. Nisin affects the growth of Listeria monocytogenes on ready-to-eat turkey ham stored at four degrees Celsius for sixtythree days. Poultry Science, Oxford, v. 89, n. 2, p. 353-358, 2010. http://dx.doi.org/10.3382/ps.2008-00503. PMid:20075290.

SANT'ANNA, V.; QUADROS, D. A.; MOTTA, A. S.; BRANDELLI, A. Antibacterial activity of bacteriocin-like substance P34 on Listeria monocytogenes in chicken sausage. Brazilian Journal of Microbiology, São Paulo, v. 44, n. 4, p. 1163-1167, 2014. http://dx.doi.org/10.1590/S1517-83822014005000004. PMid:24688506.

SAVAdogo, A.; OUATTARA, C. A. T.; BASSOle, I. H. N.; TRAORE, S. A. Bacteriocins and lactic acid bactéria: a minireview. African Journal of Biotechnology, Lagos, v. 5, p. 678-683, 2006.

UPRETI, G. C.; HINSDILL, R. D. Production and mode of action of lactocin 27: bacteriocin from a homofermentative Lactobacillus. Antimicrobial Agents and Chemotherapy, Washington, v. 7 , n. 2, p. 139-145, 1975. http://dx.doi.org/10.1128/AAC.7.2.139. PMid:1137365.

UZELAC, G.; KOJIC, M.; LOZO, J.; ALEKSANDRZAKPIEKARCZYK, T.; GABRIELSEN, C.; KRISTENSEN, T.; NES, I. F.; DIEP, D. B.; TOPISIROVIC, L.; NES, I. F.; DIEP, D. B.; TOPISIROVICA, L. A Zn-dependent metallopeptidase is responsible for sensitivity to Isbb, a class ii leaderless bacteriocin of Lactococcus lactis subsp. lactis BGMN1-5. Journal of Bacteriology, Washington, v. 195, n. 24, p. 5614-5621, 2013. http://dx.doi.org/10.1128/JB.00859-13. PMid:24123824.

VAN BELKUM, M. J.; STILES, M. E. Nonlantibiotic antibacterial peptides from lactic acid bacteria. Natural Product Reports, London, v. 17, n. 4, p. 323-335, 2000. http://dx.doi.org/10.1039/ a801347k. PMid:11014335.

YANG, S. C.; LIN, C. H.; SUNG, C. T.; FANG, J. Y. Antibacterial activities of bacteriocins: application in foods and pharmaceuticals. Frontiers in Microbiology, Lausanne, v. 5, p. 1-10, 2014.

ZACHAROF, M. P.; LOVITT, R. W. Bacteriocins produced by lactic acid bacteria: a review article. Asia-Pacific Chemical Biological and Environmental Engineering Society, Hong Kong, v. 2, p. 50-56, 2012. 